DOI: 10.21608/zvjz.2016.7835

\title{
Some Immunomodulating Effects of Diclazuril in New Zealand Rabbits
}

Gamal El-Din A.M. Shams, Abdel-Alim F. Abdel-Alim, Nagah E.M. Edrees and Abeer E. Hossny*

Pharmacology Department, Faculty of Veterinary Medicine, Zagazig University, 44511, Egypt

Article History: Received: 29/4/2016 Received in revised form: 12/6/2016 Accepted: 24/6/2016

\begin{abstract}
This study was conducted to investigate the immunomodulating effects of the diclazuril anticoccidial drug ( $1 \mathrm{mg} / \mathrm{kg} \mathrm{BW})$ given orally for 5 successive days to rabbits vaccinated with rabbit haemorrhagic viral disease (RHVD). Two blood samples were collected at the $1^{\text {st }}, 2^{\text {nd }}, 3^{\text {rd }}$, $7^{\text {th }}, 14^{\text {th }}$ and $21^{\text {st }}$ days post drug and vaccine administration to study the effect of diclazuril on the innate immune response (phagocytic activity, serum lysozyme activity and nitric oxide production) and the humoral immune response (serum total proteins, determination of serum globulins and gamma globulins fractions using electrophoretic technique). The results revealed that diclazuril had adverse effect on both the innate and humoral immune response as evidenced by a significant decrease in phagocytic activity, lysozyme activity, nitric oxide production, serum total proteins, globulins and gamma globulins in rabbits. Therefore, diclazuril is not recommended as a chemotherapeutic agent for rabbits in the dose of $1 \mathrm{mg} / \mathrm{kg} \mathrm{BW}$.
\end{abstract}

Keywords: Diclazuril, Cellular, Humoral, Immune, Serum Proteins

\section{Introduction}

Rabbits are important farm animals raised for a variety of purposes including meat, fur and wool production from some breeds. For many years, prophylactic use of anticoccidial drugs has been the primary means of controlling coccidiosis. Anticoccidial drugs such as diclazuril had a significant prophylactic effect on Eimeria stiedai infection in rabbits [1]. Diclazuril, Toltrazuril and Nicarbazin were introduced firstly and then followed by ionophores. Nowadays, these drugs are considered as a stone base component for controlling coccidiosis [2]. In order to overcome the drug resistance of Eimeria species, several researches had been done to seek alternative means of control through increased knowledge for understanding the immunomodulation and natural product feed additives [3].

Diclazuril is a chemical anticoccidial drug which is a nucleotide analogue for prevention of coccidiosis intended for use in broilers, chickens, turkeys and rabbits. Diclazuril is a benzeneacetonitrile that has potent activity against various stages of Eimeria tenella [4].
Few anticoccidials of this type have been developed [5]. Diclazuril is a very potent anticoccidial in rabbits and can be advocated for safe medication at $1 \mathrm{ppm}$ for 7 days [6]. Many studies declared the potent activity and efficacy of diclazuril against various species of Eimeria [7,8]. Some immunologic studies have been performed to detect the effect of diclazuril on innate and humoral immune response. Several researches demonstrated that the therapeutic doses of diclazuril did not interfere with formation of protective immunity to E. tenella [9,10]. Diclazuril with a dose of $2 \mathrm{ppm}$ did not affect the performance of rabbits and chickens but negative modulating effect on the humoral and cellmediated immune response has been recorded $[11,12]$. Therefore, the aim of this study was to elucidate the potential adverse effects of diclazuril on rabbits at a dose of $1 \mathrm{mg} / \mathrm{kg} \mathrm{BW}$ for 5 successive days.

*Corresponding author e-mail: (abeerhosny26@yahoo.com), Pharmacology Department, Faculty of Veterinary Medicine, Zagazig University, 44511, Egypt. 


\section{Animals and experimental design}

Eighteen New Zealand white rabbits of 3 months old and weighing about $2 \mathrm{~kg}$ were used in this study. They were purchased from a private rabbitrary without history of rabbit haemorrhagic viral disease (RHVD) outbreaks or RHVD vaccination. The rabbits were tested serologically and proved to be sero-negative for RHVD. They were housed in disinfected well ventilated metal cage and provided with ad-libitum commercial pellet ration and clean water and kept under observation for one week before being used.

Rabbits were classified into 3 groups (each of 6 rabbits) as the following; the first group was non vaccinated non treated and was kept as a negative control; the second group was vaccinated (0.5 mL RHVD S.C) non treated and was kept as a positive control. The $3^{\text {rd }}$ group was vaccinated with RHVD $(0.5 \mathrm{~mL}$ S.C) and treated by diclazuril $1 \mathrm{mg} / \mathrm{kg}$ BW (Diclosol ${ }^{\circledR}$ liquid each $1 \mathrm{~mL}$ contain diclazuril $10 \mathrm{mg}$, Pharma Swede Company) given orally for 5 successive days according to the company recommendation for lambs. Two blood samples were collected from the ear vein of 5 rabbits/group at $1^{\text {st }}, 2^{\text {nd }}, 3^{\text {rd }}, 7^{\text {th }}, 14^{\text {th }}$ and $21^{\text {st }}$ days post vaccination for studying both the innate and humoral immune responses. The first sample was $2-3 \mathrm{~mL}$ of blood collected in a sterile Wasserman tube containing heparin $(50 \mathrm{IU} / \mathrm{mL})$ to measure the phagocytic activity [13]. The second sample was $3-5 \mathrm{~mL}$ of blood collected in a sterile Wasserman tube without an anticoagulant.
These samples were allowed to clot, and the serum was separated by centrifugation at 3000 r.p.m. for $10 \mathrm{~min}$ and stored at $-20^{\circ} \mathrm{C}$ in sterile Eppendorf tubes till the time of use. Estimation of lysozyme concentration [14], nitric oxide production [15], total serum proteins [16], globulins and serum gamma globulins was carried out $[17,18]$.

\section{Statistical analysis}

Data in the present study were statistically analyzed using SPSS version 21, IBM Corp., Chicago, IL, USA. Analysis of variance (ANOVA) [19] was used to determine the effect of diclazuril on the immune parameters.

\section{Results and Discussion}

Rabbits are exposed to many negative modulating factors, such as bad hygiene, concomitant infection with other diseases, management errors and immune suppressive drugs [20]. Immune suppression is the main cause of many diseases such as cancer, autoimmune disorders and some chemotherapeutic drugs. Blood parameters serve as indicators for the effect of drugs on innate and adaptive immune response and other serum proteins. Treatment of the vaccinated (RHVD) rabbits with diclazuril (1 $\mathrm{mg} / \mathrm{kg}$ BW) decreased the phagocytic activity (phagocytosis \% and phagocytic index) significantly at the $3^{\text {rd }}$ day post vaccination. While, lysozyme concentration and nitric oxide production were decreased at $1^{\text {st }}, 2^{\text {nd }}$ and $3^{\text {rd }}$ day post vaccination compared with vaccinated non treated group.

Table 1: Effect of oral administration of diclazuril (1 mg/kg BW) for 5 successive days on phagocytosis \% and phagocytic index in vaccinated rabbits (Mean \pm S.E), $n=5$

\begin{tabular}{lcc}
\hline Groups & Phagocytic percent \% & Phagocytic index \\
\hline Control & $71.40 \pm 0.60^{\mathrm{c}}$ & $4.20 \pm 0.05^{\mathrm{c}}$ \\
Vaccinated only & $85.80 \pm 1.24^{\mathrm{a}}$ & $6.86 \pm 0.04^{\mathrm{a}}$ \\
Vaccinated and treated & $75.00 \pm 0.70^{\mathrm{b}}$ & $4.84 \pm 0.09^{\mathrm{b}}$ \\
\hline
\end{tabular}

Means within the same column carrying different letters are significant at $\mathrm{P} \leq 0.05$ 
Phagocytes act as storage for lysozyme, myeloperoxidase, acid hydrolysis, and complement activators [21]. The decrease in phagocytic percent and index (Table 1) express the adverse effect of diclazuril (1 $\mathrm{mg} / \mathrm{kg} \mathrm{BW}$ ). These results were in agreement with Hassan et al. [11] who reported that administration of $2 \mathrm{ppm}$ diclazuril given for 7 weeks with diet for New Zealand rabbits lead to leukopenia and neutrophilia. Lysozyme is part of the innate immune system which is a major secretory product of macrophages with antimicrobial and immunomodulating actions which reflect on the activities of macrophages [21]. The reduction of lysozyme concentration was significantly noticed as a side effect of diclazuril administration (Table 2).

Table 2: Effect of oral administration of diclazuril (1 $\mathrm{mg} / \mathrm{kg} \mathrm{BW})$ for 5 successive days on lysozyme concentration $(\mu \mathrm{g} / \mathrm{mL})$ in vaccinated rabbits $($ Mean \pm S.E $), n=5$

\begin{tabular}{llll}
\hline Groups & \multicolumn{2}{l}{ Serum lysozyme conc. $(\boldsymbol{\mu g} / \mathbf{m L})$} & \\
& $\mathbf{1}^{\text {st }}$ day & $\mathbf{2}^{\text {nd }}$ day & $\mathbf{3}^{\text {rd }}$ day \\
\hline Control & $120.0 \pm 0.70^{\mathrm{c}}$ & $130.0 \pm 0.31^{\mathrm{c}}$ & $137.0 \pm 0.32^{\mathrm{b}}$ \\
Vaccinated only & $190.60 \pm 0.40^{\mathrm{a}}$ & $197.0 \pm 0.32^{\mathrm{a}}$ & $191.80 \pm 0.48^{\mathrm{a}}$ \\
Vaccinated and treated & $130.40 \pm 0.50^{\mathrm{b}}$ & $140.6 \pm 0.40^{\mathrm{b}}$ & $135.60 \pm 0.40^{\mathrm{c}}$ \\
\hline
\end{tabular}

Means within the same column carrying different letters are significant at $\mathrm{P} \leq 0.05$

Table 3: Effect of oral administration of diclazuril $(1 \mathrm{mg} / \mathrm{kg} \mathrm{BW})$ for 5 successive days on serum niric oxide production $(\mu \mathrm{g} / \mathrm{mL})$ in vaccinated rabbits, $($ Mean \pm S.E $) n=5$

\begin{tabular}{llll}
\hline Groups & \multicolumn{2}{l}{ Serum nitric oxide production $(\boldsymbol{\mu g} / \mathbf{m L})$} & $\mathbf{3}^{\text {rd }}$ day \\
\hline Control & $18.82 \pm 0.32^{\mathrm{b}}$ & $19.10 \pm 0.35^{\mathrm{b}}$ & $18.88 \pm 0.46^{\mathrm{b}}$ \\
Vaccinated only & $27.70 \pm 1.11^{\mathrm{a}}$ & $28.28 \pm 1.53^{\mathrm{a}}$ & $27.60 \pm 0.92^{\mathrm{a}}$ \\
Vaccinated and treated & $21.36 \pm 1.92^{\mathrm{b}}$ & $21.02 \pm 1.33^{\mathrm{b}}$ & $22.30 \pm 1.68^{\mathrm{b}}$ \\
\hline
\end{tabular}

Means within the same column carrying different letters are significant at $\mathrm{P} \leq 0.05$

Concerning nitric oxide (NO) which is considered a product of immune system cells such as macrophages is a potent biological effector regulating blood vessels dilatation, serving as a neural messenger and playing a complex role in inflammatory response. It is activated by cytokine microbial compounds which are derived from amino acid L-arginine by the enzymatic activity of inducible nitric oxide synthase (iNOS) and functions as a tumoricidal and antimicrobial molecule in vitro [22]. The current investigation revealed significant reduction of nitric oxide production which was supported by Mohammed [12] who stated that 2 ppm diclazuril administration resulted in a significant reduction in the percent of monocytes, basophils and heterophils which play an important role in phagocytosis. It was found in the present investigation that the production of nitric oxide was significantly decreased. Consequently, it could be concluded that these cells are responsible for nitric oxide release. The results demonstrated the positive correlation between nitric oxide production and lysozyme concentration. 
Table 4: Effect of oral administration of diclazuril $(1 \mathrm{mg} / \mathrm{kg} \mathrm{BW}$ ) for 5 successive days on total serum protein level $(\mathrm{g} / \mathrm{dl})$ in vaccinated rabbits, $($ Mean \pm S.E) $n=5$

\begin{tabular}{|c|c|c|c|}
\hline \multirow{2}{*}{ Groups } & \multicolumn{3}{|c|}{ Total protein g/dl } \\
\hline & $\mathbf{1}^{\text {st }}$ week & $2^{\text {nd }}$ week & $3^{\text {rd }}$ week \\
\hline Control & $5.08 \pm 0.10^{b}$ & $5.00 \pm 0.07^{b}$ & $5.40 \pm 0.12^{b}$ \\
\hline Vaccinated only & $7.32 \pm 0.06^{\mathrm{a}}$ & $7.10 \pm 0.31^{\mathrm{a}}$ & $7.78 \pm 0.07^{a}$ \\
\hline Vaccinated and treated & $5.24 \pm 0.05^{\mathrm{b}}$ & $6.42 \pm 0.14^{\mathrm{a}}$ & $7.28 \pm 0.14^{a}$ \\
\hline
\end{tabular}

Means within the same column carrying different letters are significant at $\mathrm{P} \leq 0.05$.

The current study illustrated a proteinogram analysis (Tables 4). A significant decrease in total serum protein (hypoprotienemia) at $1^{\text {st }}$ week post vaccination was recorded in comparison with vaccinated non treated. A high significant decrease in gamma globulins (\%) all over the experimental period was obvious when compared with vaccinated non treated group (Table 5).

Table 5: Effect of oral administration of diclazuril (1 mg/kg BW) for 5 successive days on serum gammaglobulins $(\%)$ in vaccinated rabbits, $($ Mean \pm S.E) $n=3$

\begin{tabular}{lccc}
\hline Groups & \multicolumn{3}{c}{ protein fraction (gamma \%) } \\
& $\mathbf{1}^{\text {st }}$ week & $\mathbf{2}^{\text {nd }}$ week & $\mathbf{3}^{\text {rd }}$ week \\
\hline Control & $16.34 \pm 0.10^{\mathrm{c}}$ & $16.40 \pm 0.01^{\mathrm{c}}$ & $16.80 \pm 0.01^{\mathrm{c}}$ \\
Vaccinated only & $18.64 \pm 0.01^{\mathrm{a}}$ & $18.51 \pm 0.01^{\mathrm{a}}$ & $18.64 \pm 0.01^{\mathrm{a}}$ \\
Vaccinated and treated & $15.47 \pm 0.02^{\mathrm{b}}$ & $16.21 \pm 0.02^{\mathrm{b}}$ & $17.30 \pm 0.01^{\mathrm{b}}$ \\
\hline
\end{tabular}

Means within the same column carrying different letters are significant at $\mathrm{P} \leq 0.05$.

The decrease in total serum proteins after the first week of the experiment is going with the main stream of the adverse effect of the diclazuril on the immune system. The decrease in serum globulins level is attributed to the reduction in antibodies produced by B-cells, the reconstruction, activation and hyperplasia of lympho-reticular cells at the beginning of immunogenesis. The reduction of globulins synthesis is one of the factors which lead to immune deficiency which resulted from malfunction of lymphocytes. These results were in agreement with those previously reported by El-Kahkey [23] who measured the effect of two doses of semduramicin (25 and $50 \mathrm{ppm}$ ) on the cellular and humoral immune response on broiler chickens vaccinated against Newcastle viral disease. The author reported that $50 \mathrm{ppm}$ had non-significant changes in albumins but a significant decrease in serum gamma globulins at the $1^{\text {st }}$ and $3^{\text {rd }}$ week post vaccination at both dose (25 and 50 ppm) of semduramicin.
Our results were also in accordance with Abdel-Hafez [24] who reported that 2 ppm of diclazuril decreased the total serum proteins and globulins level (gamma-globulins). The observed decrease in gamma-globulins at $1^{\text {st }}$ and $2^{\text {nd }}$ week post vaccination may be due to the negative effect of diclazuril on the lymphoid organs which is considered the main part in synthesis of gamma globulins as reported by Cooper et al. [25].

\section{Conclusion}

In conclusion, particular chemotherapeutics such as diclazuril lead to immune deficiency" secondary immune deficiency", which refers to augment disease risk. Therefore, diclazuril is not recommended in the current dose for treating coccidia in rabbits.

\section{Conflict of interest}

The authors declare no conflict of interest. 


\section{References}

[1] Jiang, J.S.; Yin, P.Y. and Han, Q. (1991): Therapeutic efficacy of diclazuril, monesin and salinomycin against hepatic coccidiosis in rabbits. Chinese J Vet Sci Technol, 21(10): 3738 .

[2] Chapman, H.D. (1999): Anticoccidial drugs and their effects upon the development of immunity to Eimeria infections in poultry. Avian Pathol, 28(6):521-535.

[3] Kitandu, A. and Juranov, R. (2006): Progress in control measures for chicken coccidiosis. Acta Veterinaria Brno, 75(2): 265276.

[4] Zhou, B.; Wang, H.; Xue, F.; Wang, X.; Fei, C.; Wang, M.; Zhang, T.; Yao, X. and He, P. (2010): Effects of diclazuril on apoptosis and mitochondrial transmembrane potential in second generation merozoites of Eimeria tenella. Vet Parasitol,168(3): 217-222.

[5] Abbas, R.Z.; Iqbal, Z.; Khan, M.N.; Hashmi, N. and Hussain, A. (2009): Prophylactic effect of diclazuril in broilers experimentally infected with three field isolates of Eimeria tenella. Int J Agric Biol, 11 (5): 606-610.

[6] Vanparijs, O.; Hermans, L.; van der Flaes, L. and Marsboom, R. (1989): Efficacy of diclazuril in the prevention and cure of intestinal and hepatic coccidiosis in rabbits. Vet Parasitol, 32: 109-117.

[7] McDougald, L.R.; Mathis, G.F. and Seibert, B.P. (1990): Anticoccidial efficacy of diclazuril against field isolates of Eimeria from commercial poultry farms. Avian Dis, 35(4): 911-915.

[8] Du, A. and Hu, S. (2004): Effects of a herbal complex against Eimeria tenella infection in chickens. J Vet Med, Series B, 51(4):194-197.

[9] Maes, L.; Vanparus, O. and Mareboom, R. (1991): Effect of diclazuril (Clinacox) ${ }^{\circledR}$ on the development of protective immunity against Eimeria tenella: Laboratory trial in broiler chickens. Poult Sci, 70(3): 504-508.
[10] Maes, L. and Hermans, L. (1992): Effects of diclazuril (Clinacox) ${ }^{\circledR}$ on the development of protective immunity in pullets. Proceedings of the $19^{\text {th }}$ World Poultry Congress, Amsterdam, 107-110.

[11] Hassan, M.; Mohamed, S., Fatti, F. and Hesham, S. (1999): Effect of diclazuril on performance and immune response in rabbits. Al-azhar Med J, 28(2):183-191.

[12] Mohammed, M.I.M. (1999): Effect of clopidol, diclazuril and maduramycin on immune response of chickens vaccinated with Newcastle disease vaccine. $\mathrm{PhD}$ thesis, Faculty of Veterinary Medicine, Cairo University.

[13] Lee, L.F. and Baccon, L.D. (1982): Ontageny and line differences as in mitogenic responses of chicken Lymphocytes. Poultry Sci, 62:579-594.

[14] Mohrig, W.; Messner, B. (1968): Immunreaktionen bei Insekten. Lysozym als grundlegender antibakterieller Faktor im humoralen Abwehrsystem der Insekten. Biol Zbl, 4:439-470. Cited after: Jacot, A.; Scheuber, H.; Kurtz, J. and Brinkhof, M.W.G. (2005): Juvenile immune system activation induces a costly upregulation of adult immunity in field crickets Gryllus campestris. Proc R Soc Lond B Biol Sci, 272 (1558): 63-9

[15] Rajarman, V.; Nonnecke, B.J.; Franklin, S.T.; Hamell, D.C. and Horst, R.L. (1998): Effect of vitamins $A$ and $E$ on nitric oxide production by blood mononuclear leukocytes from neonatal calves fed milk replacer. J Dairy Sci, 81(12):3278-3285.

[16] Gornal, A.G.; Bardawil, C.J. and David, M.M. (1949): Determination of serum proteins by means of biuret reaction. J Biol Chem, 177:751-766.

[17] Davis, B.J. (1964): Disc electrophoresis, methods and application to human serum proteins. J Ann New York Acad Sci,121: 404428.

[18] Ornstein, L. (1964): Disc electrophoresis background and theory. J Ann New York Acad Sci, 121:321. 
[19] Snedecor, G.W. and Cochran, W.G. (1982): Statistical methods. $6^{\text {th }}$ Ed. The Iowa State University, Press Ames, USA., Pages:593.

[20] Abd El-Khalek, M.A. and Hady, O.A. (2007): Effect of propionobacterium and $E$. coli lipopolysaccharide (immunair 17.5) immunomodulator on response of rabbits to RHVD vaccine. Beni Suef Vet Med J, $5^{\text {th }}$ Scientific Conference, PP 69-72.

[21] Farthmann, E. and Schoffel, U. (1998): Epidemiology and pathophysiology of IAI. Infection, 26:329-34.

[22] Nathan, C. (1992): Nitric oxide as a secretory product of mammalian cells. The FASEB journal, 6(12):3051-3064.
[23] El-Kahkey, M. (1998): Effect of semduramycin on the immune response in chickens vaccinated with Newcastle disease virus. $\mathrm{PhD}$ thesis, Faculty of Veterinary Medicine, Zagazig University.

[24] Abdel-Hafez, G.M. (2004): Pharmacological study on the effect of diclazuril and flavomycin alone and combination on performance and immune response in chickens. $\mathrm{PhD}$ thesis (pharmacology), Faculty of Veterinary Medicine, Kafr El Sheikh, Tanta University.

[25] Cooper, M.D.; Van Alten, P.; Cain, W.A. and Good, R.A. (1969): Development and function of the Immunoglobulin producing system. Int Arch Allergy Appl Immunol, 35(3):242-252.

$$
\begin{aligned}
& \text { الملخص العربى } \\
& \text { بعض التأثثرات المناعية للايكلازوريل فى الأراتب النيوزلانديه } \\
& \text { جمال الدين محروس شمس، عبد العليم فؤاد عبد العليم،نجاح السيد إدريس ,عبير السيد حسنى } \\
& \text { قسم الفارماكولوجيا، كلية الطب البيطري جامعة الزقازيق }
\end{aligned}
$$

تم إجر اء هذة الدراسة لبيان التأثير المناعى للدايكلازوريل (ا مجم/كجم من وزن الجسم) عند إعطائة لمدة خمسة أبام متتالية

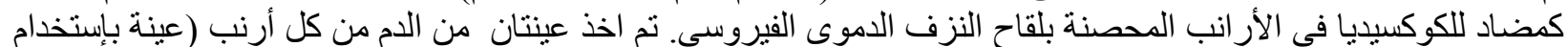

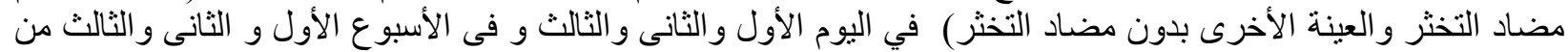

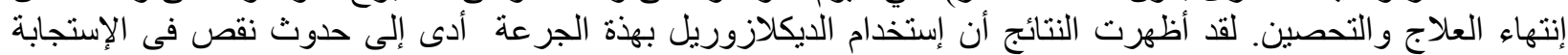

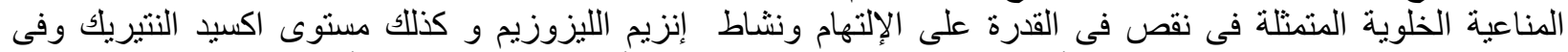

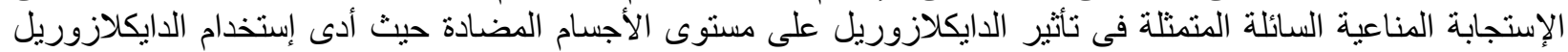

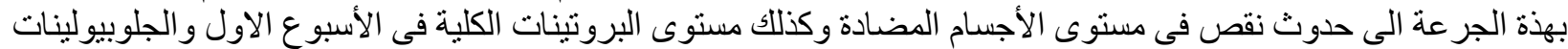
من نوع جاما و أجز اء البروتينات المختلفة. لذلك لا يفضل إستخدام الدايكلازوريل بهذة الجر عة لعلاج الأر انب . 